\title{
PEMANFAATAN BIJI KELOR (Moringa oleifera L.) SEBAGAI PASTA GIGI
}

\author{
Utilization of Moringa Seed (Moringa oleifera L.) as Toothpaste
}

\author{
*Ahmad Ma'ruf, Supriadi, dan Siti Nuryanti \\ Pendidikan Kimia/FKIP - Universitas Tadulako, Palu - Indonesia 94118 \\ Received 03 March 2016, Revised 05 April 2016, Accepted 04 May2016
}

\begin{abstract}
Moringa seed (moringa oleifera L.) is a kind foodstuffs that contains calcium. Calcium is a mineral that is needed by our bodies in all ages, for the infants to the elderly. Calcium is useful in the formation and maintenance of bones and teeth. The aim of this study is to determine the concentration calcium (Ca) in moringa seed (moringa oleifera L.) and its utilization as the fabrication of toothpaste. The method used in this study is a laboratory experiment using a flame photometer. The results showed that the concentration of calcium in moringa seeds with three repetitions is $131.67 \pm 12.58 \mathrm{mg} /$ $100 \mathrm{~g}$. The appropriate composition of materials to make toothpaste from moringa seeds including the roughness tests of toothpaste and based on the fondness of panelists is 25:5 (morinanga seed:NaHCO3). Furthermore, the test of freshness, aroma, and colour with comparison of glycerin, mint leaves, betel leaves and food coloring 7.5: 5: 5: 2.
\end{abstract}

Keywords: Toothpaste, concentration of calcium (Ca), Moringa seeds (Moringa oleifera L.), and flame photometer.

\section{Pendahuluan}

Tanaman kelor (moringa oleifera L) merupakan tanaman khas daerah tropis yang juga mudah tumbuh. Tanaman kelor di Indonesia sudah banyak dijumpai di Aceh, Kalimantan, Ujung Pandang dan Kupang (Fahey, 2005). Tanaman kelor juga sudah menyebar di luar negeri yakni di daerah Afrika dan seluruh Asia yang sebagian besar memiliki iklim tropis seperti di Indonesia. Pohon kelor sudah dikenal luas di Indonesia sebagai tanaman obat khususnya di daerah pedesaan, tetapi belum dimanfaatkan secara maksimal dalam kehidupan (Hariana, 2008).

Kelor menjadi sumber antioksidan alami yang baik karena kandungan dari berbagai jenis senyawa antioksidan seperti vitamin C, flavonoid, phenolic dan karotenoid (Becker \& Makkar, 1996). Tingginya konsentrasi vitamin $\mathrm{C}$, zat estrogen dan $\beta$-sitosterol, besi, kalsium, fosforus, tembaga, vitamin A, B, $\alpha$-tokoferol, riboflavin, nikotinik, asam folat, piridoksin, $\beta$-karoten, protein, dan khususnya asam amino esensial seperti metionin, sistin, triptofan dan lisin yang terdapat dalam daun dan polong

*Correspondence:

Ahmad Ma'ruf

Program Studi Pendidikan Kimia, Fakultas Keguruan dan

IImu Pendidikan, Universitas Tadulako

email:marufahmad93@gmail.com

Published by Universitas Tadulako 2016 yang membuatnya menjadi suplemen makanan yang hampir ideal (Fahey, 2005).

Pohon kelor memiliki daun yang mengandung nutrisi paling lengkap dibanding dengan tumbuhan jenis apapun. Selain vitamin dan mineral, daun kelor juga mengandung semua asam amino esensial (asam amino yang tidak diproduksi sendiri oleh tubuh). Oleh karena itu, daun kelordapat dimanfaatkan sebagai makanan alternatif padakasus malnutrisi. Penduduk Indonesia terutama dipedesaan, juga sering menggunakan daun kelor sebagaiobat tradisional. Di India jus daun kelor digunakanuntuk menstabilkan tekanan darah. Selain itu, daun kelor dipercaya dapat mengontrolkadar glukosa pada penderita Diabetes Mellitus. Di Indonesia daun kelor digunakan juga sebagai obatmenurunkan kolesterol, diare, disentri, colitis, gonorhea,sakit kepala, anemia, iritasi, infeksi, antialergi,antikarsinogenik, antihelminthes dan anti inflamasi(Wihastuti, dkk., 2007).

Tumbuhan kelor ini berasa agak pahit, bersifat netral dan tentu saja tidak beracun. Kulit akarnya mengandung minyak atsiri (yang mudah menguap). Biji tumbuhan kelor mengandung alkaloid, vitamin $\mathrm{A}, \mathrm{B} 1, \mathrm{~B} 2$ dan C pada sel-sel tertentu. Efek farmakologis yang dimiliki oleh kelor adalah sebagai anti- 
inflamasi, anti-piretik dan antiskorbut (Kholis \& Hadi, 2010).

Kandungan kimia yang dimiliki tanaman kelor antara lain asam amino seperti asam aspartat, asam glutamat, alanin, valin, leusin, isoleusin, histidin, lisin, arginin, venilalanin, triftopan, sistein dan methionin. Selain itu daun kelor juga mengandung unsur makro seperti potasium, kalsium, magnesium, sodium, dan fosfor, serta unsur mikro seperti mangan, seng, dan besi. Daun kelor merupakan sumber provitamin $A$, vitamin $B$, vitamin $C$, mineral terutama zat besi dan kalsium (Boukes, dkk., 2008).Masyarakat di beberapa daerah di Indonesia memanfaatkan daun kelor sebagai sayuran, terutama untuk memperbanyak dan melancarkan ASI. Daun kelor juga mengandung Vitamin C lebih banyak dibanding jeruk dan kalsium empat kali lipat kalsium susu (Sutanto, dkk., 2007).

Kalsium merupakan salah satu nutrient esensial yang dibutuhkan untuk berbagai fungsi tubuh diantaranya berperan dalam pembentukan tulang dan gigi. Kalsium merupakan salah satu mineral yang terdapat di dalam tubuh dan memegang peranan penting dalam pemeliharaan fungsi tubuh, baik tingkat sel, jaringan, organ maupun fungsi tubuh secara keseluruhan. Keseimbangan mineral di dalam tubuh diperlukan untuk pengaturan kerja enzim, pemeliharaan keseimbangan asam basa, pemeliharaan kepekaan otot dan saraf terhadap rangsangan (Almaitser, 2004). Kalsium adalah mineral yang paling banyak dibutuhkan oleh tubuh, terdapat dalam jumlah 1,5-2\% dari keseluruhan berat tubuh. Lebih dari 99\% kalsium terdapat dalam tulang. Kalsium juga merupakan komponen penting dalam pembentukkan gigi. Kalsium sangat penting untuk mengatur sejumlah besar aktivitas fungsi saraf dan otot, kerja hormon serta pembekuan darah. Konsumsi kalsium sejak dini dapat mencegah terjadinya osteoporosis di masa tua (Afrianti \& Harun, 2011).

Kandungan kalsium dari buah kelor sangat tinggi sehingga sangat dimungkinkan untuk bahan dasar pasta gigi karena kalsium berperan sebagai bahan abrasif yang terdapat dalam pasta gigi yang berfungsi untuk membersihkan dan memoles permukaan gigi tanpa merusak email, mempertahankan ketebalan pelikel, serta mencegah akumulasi stain. Bentuk dan jumlah bahan abrasif dalam pasta gigi membantu untuk menambah kekentalan pasta gigi (Cahyadi, 2006).

Pasta gigi adalah salah satu produk kosmetik yang digunakan tidak hanya untuk orang dewasa tetapi juga anak-anak. Fungsinya untuk membersihkan gigi dari sisa-sisa makanan atau minuman, menjaga kesehatan gigi dan gusi dan menghilangkan bau yang disebabkan oleh aktivitas bakteri di dalam mulut (Maharani, dkk., 2009).

Menurut Maharani dkk., (2009) Umumnya pasta gigi yang beredar di pasaran saat ini adalah kombinasi dari bahan abrasif, deterjen dan satu atau lebih bahan terapeutik.

\section{a. Bahan abrasif (30-40\%)}

Bahan abrasif yang terdapat dalam pasta gigi berfungsi untuk membersihkan dan memoles permukaan gigi tanpa merusak email, mempertahankan ketebalan pelikel, serta mencegah akumulasi stain. Bentuk dan jumlah bahan abrasif dalam pasta gigi membantu untuk menambah kekentalan pasta gigi. Contoh bahan abrasif ini antara lain silica atau silica hydrat, sodium bikarbonat, aluminium oxide, dikalsium fosfat dan kalsium karbonat.

\section{b. Air}

Air dalam pasta gigi berfungsi sebagai pelarut bagi sebagian bahan dan mempertahankan konsistensi.

\section{c. Pelembab atau Humectant (10-30\%)}

Humectant adalah bahan penyerap air dari udara dan menjaga kelembaban. Misalnya gliserin, alpha hydroxy acids (AHA) dan asam laktat. Bahan ini digunakan untuk menjaga pasta gigi tetap lembab.

\section{d. Bahan perekat (1-5\%)}

Bahan perekat ini berfungsi mengikat semua bahan dan membantu memberi tekstur pada pasta gigi. Contohnya Karboksimetil sellulose, Hidroksimetil sellulose, Carragaenan, dan Cellulose gum.

e. Surfectan atau Deterjen (1-2\%)

Bahan deterjen yang banyak terdapat dalam pasta gigi di pasaran adalah Sodium Lauryl Sulfat (SLS) yang berfungsi menurunkan tegangan permukaan dan melonggarkan ikatan debris dengan gigi yang akan membantu gerakan pembersihan sikat gigi.

\section{f. Bahan penambah rasa (1-5\%)}

Fungsi penggunaan bahan penambah rasa pada pasta gigi adalah untuk menutup rasa bahan-bahan lain yang kurang enak terutama SLS dan untuk memenuhi selera pengguna. Contoh bahan penambah rasa yang digunakan adalah Pepermint/spearmint, Menthol, Eucalyptus, Anniseed, dan Sakharin.

\section{g. Bahan terapeutik}

Bahan terapeutik yang terdapat dalam pasta gigi adalah sebagai berikut:

1. Fluoride

Penambahan fluoride pada pasta gigi adalah 
sebagai bahan antikaries dimana fluoride ini dapat memperkuat enamel dengan cara membuatnya resisten terhadap asam dan menghambat bakteri untuk memproduksi asam.

\section{Bahan desensitisasi}

Bahan desensitisasi yang digunakan dalam pasta gigi misalnya Strontium kloride, Strontium asetat, Kalium Nitrat, dan Kalium Sitrat. Bahan desensitasi ini berguna untuk mengurangi atau menghilangkan sensitivitas dentin dengan cara efek desensitasi langsung pada serabut saraf.

3. Bahan anti-kalkulus

Bahan ini digunakan untuk menghambat mineralisasi plak serta mengubah $\mathrm{pH}$ untuk mengurangi pembentukan kalkulus. Contoh bahan anti-kalkulus ini adalah Pyrophosphatase, Ureat, dan Zinc Citrate.

\section{Bahan anti-plak}

Bahan ini merupakan bahan antibakteri dam dapat mengurangi pembentukan plak. Contoh bahan ini adalah Trikolsan (bakterisidal), Zinc citrate atau Zinc phosphate (bakteriostatik). Selain itu ada beberapa herbal yang ditambahkan sebagai anti mikroba dalam pasta gigi contohnya ekstrak daun sirih dan siwak.

\section{Bikarbonat}

Bikarbonat juga merupakan salah satu komponen dalam pasta gigi yang ditambahkan untuk mengurangi keasaman plak gigi.

\section{h. Bahan pengawet ( $\geq 1 \%$ )}

Bahan pengawet berfungsi untuk mencegah kontaminasi bakteri dan mempertahankan keaslian produk. Umumya bahan pengawet yang ditambahkan dalam pasta gigi adalah Natrium benzoate, Formalin dan alcohol.

\section{Metode \\ Alat dan Bahan}

Alat-alat yang digunakan dalam penelitian ini adalah Flame photometer $(B W B \quad X P$ 2011), neraca analitik (AND GR-200), labu takar, gelas kimia, Erlenmeyer, pipet ukur, batang pengaduk, cawan porselin dan oven.. Sedangkan bahan-bahan yang digunakan dalam penelitian semua berkualitas proanalisis (p.a), kecuali yang disebut adalah seperti ini adalah $\mathrm{HNO}_{3}$ (Merck), larutan standar Kalsium (Merck), $\mathrm{NaHCO}_{3}$ (Merck), gliserin,aquades, biji kelor, daun mint, daun sirih, dan pewarna makanan.

\section{Cara Kerja}

Proses penentuan kadar mineral bahan pangan, bahan harus didestruksi terlebih dulu dengan cara menimbang sebanyak 1 gram yang telah diabukan. Kemudian menambahkan $5 \mathrm{~mL}$ $\mathrm{HNO}_{3}$ p.a. dan biarkan 1 malam. Kemudian sampel dipanaskan dengan suhu $100^{\circ} \mathrm{C}$ selama satu jam dan selanjutnya dinaikkan suhunya hingga $150^{\circ} \mathrm{C}$, selanjutnya ektrak diencerkan dengan air hingga volume tepat $50 \mathrm{~mL}$ dan dikocok hingga homogen. Hasil pengenceran tersebut dianalisis menggunakan flame photometer.

Pasta gigi dari biji kelor ini dibuat dengan menambahkan natrium bikarbonat $\left(\mathrm{NaHCO}_{3}\right)$, diaduk dan ditambahkan dengan gliserin, ekstrak daun mint, ekstrak daun sirih dan pewarna makanan. Kemudian dicampurkan hingga membentuk pasta.

\section{Analisis data}

Berdasarkan hasil pengukuran yang diperolehmenggunakanalatFlame photometer, maka data yang diperoleh dapat dihitung menggunakan persamaan:

$$
Y=V \times \frac{x}{m} \times f p
$$

Dimana: $Y=$ Kadar logam dalam sampel $(\mathrm{mg} / \mathrm{g}) ; \mathrm{x}=$ Konsentrasi sampel $(\mathrm{mg} / \mathrm{L}) ; \mathrm{m}=$ Berat sampel kering $(\mathrm{g}) ; \mathrm{V}=$ Volume penetapan sampel $(\mathrm{mL})$; $\mathrm{fp}=$ Faktor pengenceran (Khopkar, 2010).

\section{Hasil dan Pembahasan}

Penelitian ini dilakukan untuk menganalisis logam Kalsium (Ca) pada biji kelor (Moringa oleifera L.), yang tumbuh di Kelurahan Tondo Kecamatan Mantikulore Kota Palu dan dianalisis menggunakan flame Photometer.

\section{Kadar Kalsium pada Sampel}

Kandungan kadar pada suatu sampel dapat ditentukan dengan menggunakan persamaan: $\mathrm{Y}=\mathrm{V} \cdot \mathrm{x} / \mathrm{m}$. Hasil analisis kadar kalsium yang diperoleh dapat diringkaskan pada Tabel 1 .

Tabel 1. Kadar kalsium dalam biji kelor

\begin{tabular}{ccccccc}
\hline Pengulangan & $\begin{array}{c}\text { Berat } \\
\text { sampel } \\
\text { kering }(\mathrm{m}) \\
\text { (gram) }\end{array}$ & $\begin{array}{c}\text { Volume } \\
\text { penetapan } \\
(\mathrm{V})(\mathrm{mL})\end{array}$ & $\begin{array}{c}\text { Faktor } \\
\text { pengenceran } \\
(\mathrm{k} \text { kali) }\end{array}$ & $\begin{array}{c}\text { Konsentrasi } \\
\text { sampel (x) } \\
(\mathrm{mg} / \mathrm{L})\end{array}$ & $\begin{array}{c}\text { Kadar } \\
\text { kalsium } \\
(\mathrm{Y}) \\
(\mathrm{mg} / 100 \mathrm{~g})\end{array}$ & $\begin{array}{c}\text { Standar } \\
\text { Deviasi }\end{array}$ \\
\hline I & 1 & 50 & 10 & 24 & 120 & 13,91 \\
II & 1 & 50 & 10 & 29 & 145 & 15,89 \\
III & 1 & 50 & 10 & 26 & 130 & 2,00 \\
\hline Rata-rata & & & & & 131 & 12,58 \\
\hline
\end{tabular}


Analisis kandungan mineral dalam pangan dapat dilakukan dengan metode analisis sederhana, seperti metode analisis gravimetri. Analisis gravimetri adalah proses isolasi dan pengukuran berat suatu unsur atau suatu senyawa tertentu. Berat unsur dihitung berdasarkan rumus senyawa dan berat atom unsur-unsur yang menyusunnya. Pemisahan unsur-unsur atau senyawa yang dikandung dilakukan dengan beberapa cara seperti: metode pengendapan, metode penguapan, atau berbagai metode lainnya. Metode gravimetri memakan waktu yang cukup lama, adanya pengotor pada konstituen dapat diuji dan bila perlu faktor-faktor koreksi dapat digunakan (Hendayana, 1994).

Analisis kandungan mineral suatu makanan dilakukan dengan cara didestruksi terlebih dahulu. Destruksi merupakan suatu perlakuan untuk melarutkan atau mengubah sampel menjadi bentuk materi yang dapat diukur sehingga kandungan berupa unsur-unsur didalamnya dapat dianalisis. Secara umum ada dua jenis destruksi yang dikenal yaitu destruksi basah dan destruksi kering. Namun, dalam penelitian ini menggunakan destruksi kering (Khopkar, 2010).

Destruksi kering adalah perombakan sampel dengan asam kuat baik tunggal maupun campuran. Pelarut yang digunakan untuk destruksi kering pada penelitian ini yaitu asam nitrat $\left(\mathrm{HNO}_{3}\right)$. Kesempurnaan destruksi ditandai dengan diperolehnya larutan jernih pada larutan destruksi, yang menunjukkan bahwa semua konstituen yang ada telah larut sempurna atau perombakan senyawa-senyawa organik telah berjalan dengan baik (Marzuki, dkk., 2013).

Penelitian dengan tahap destruksi ini, sampel biji kelor dikeringkan dengan cara dikering anginkan yang berfungs untuk menghilangkan kadar air pada sampel yang akan dianalisis, kemudian sampel dihaluskan menggunakan blender. Sampel yang akan dianalisis ditambahkan dengan larutan $\mathrm{HNO}_{3}$ yang berfungsi untuk melarutkan atau menghancurkan logam-logam yang terdapat dalam sampel karena asam nitrat dapat menstabilkan logam-logam yang akan dianalisis, lalu sampel didiamkan semalaman pada lemari asam dan keesokan harinya sampel dipanaskan pada suhu $100^{\circ} \mathrm{C}$ selama satu jam dan kemudian dinaikkan suhunya hingga $150^{\circ} \mathrm{C}$. Pendiaman sampel semalaman ini berfungsi untuk melarutkan dan memutuskan ikatan-ikatan organik. Sedangkan pemanasan berfungsi untuk membantu mempercepat proses pelarutan atau pemutusan ikatan-ikatan organik. Setelah itu sampel diencerkan dan hasil pengenceran tersebut dianalisis menggunakan flame photometer (Day \& Underwood, 2003).

Kalsium yang terdapat pada biji kelor merupakan mineral yang sangat dibutuhkan oleh tubuh di segala usia, mulai dari bayi sampai lanjut usia. Kalsium berguna dalam pembentukan dan pemeliharaan tulang dan gigi(Almaitser, 2004).

Beberapa faktor yang dapat menghalangi penyerapan kalsium pada tanaman adalah adanya zat organik yang dapat bergabung dengan kalsium dan membentuk garam yang tidak larut. Contoh dari senyawa tersebut adalah asam okslat dan asam fitrat. Asam oksalat dan kalsium membentuk garam yang tidak larut, yaitu kalsium oksalat. Asam oksalat banyak ditemukan di dalam bibit yang masih hijau, sedangkan asam fitrat terdapat dalam bekatul gandum (Winarno, 2004).

Setelah perlakuan analisis kandungan kalsium pada biji kelor. Maka selanjutnya adalah pemanfaatan biji kelor sebagai bahan dasar pembuatan pasta gigi. Kalsium yang terkandung dalam biji kelor tersebut berfungsi sebagai bahan penggosok (Polishing) untuk menghilangkan partikel-partikel sisa makanan yang menempel pada gigi. Pasta gigi ini juga menggunakan ekstrak daun mint yang berfungsi sebagai penyegar serta ekstrak daun sirih yang berfungsi sebagai anti kuman. Selain itu juga ditambahkan Natrium Bikarbonat $\left(\mathrm{NaHCO}_{3}\right)$ sebagai bahan abrasif yang berfungsi memoles dan menghilangkan stain dan plak gigi.

Uji organoleptik merupakan parameter yang penting untuk melihat kesukaan dan penerimaan konsumen terhadap produk. Uji ini menggunakan panelis untuk mengetahui sifat sensorik tertentu. Pada penelitian ini dilakukan uji organoleptik dengan panelis adalah mahasiswa yang berjumlah 15 orang. Uji ini meliputi uji kekesatan, kesegaran, aroma, dan warna dari pasta gigi biji kelor. Uji organoleptik pada pasta gigi ini mengacu pada Standar Nasional Indonesia 12 - 3524 - 1995 (Putri, 2008). 
Tabel 2. Hasil Uji Organoleptik dari pasta gigi

\begin{tabular}{ccccc}
\hline Panelis & Kekesatan & Kesegaran & Aroma & Warna \\
\hline 1 & 4 & 3 & 4 & 4 \\
2 & 3 & 3 & 4 & 3 \\
3 & 3 & 3 & 3 & 4 \\
4 & 4 & 3 & 4 & 4 \\
5 & 3 & 3 & 3 & 4 \\
6 & 4 & 3 & 3 & 4 \\
7 & 2 & 3 & 4 & 4 \\
8 & 4 & 4 & 3 & 3 \\
9 & 3 & 3 & 4 & 4 \\
10 & 4 & 4 & 3 & 3 \\
11 & 4 & 2 & 3 & 2 \\
12 & 3 & 3 & 3 & 3 \\
13 & 4 & 4 & 3 & 4 \\
14 & 3 & 3 & 3 & 3 \\
15 & 3 & 4 & 4 & 3 \\
\hline Jumlah & 51 & 48 & 51 & 52 \\
\hline Rata- & 3,4 & 3,2 & 3,4 & 3,5 \\
rata & & & & \\
\hline & & & &
\end{tabular}

Komposisi bahan yang tepat untuk membuat pasta gigi dari biji kelor meliputi uji kekesatan dari pasta gigi berdasarkan kesukaan panelis yaitu dengan perbandingan biji kelor dan $\mathrm{NaHCO} 3$ sebanyak 25 : 3. Sedangkan untuk uji kesegaran, aroma dan warna dengan perbandingan gliserin, daun mint, daun sirih dan pewarna makanan sebanyak $7,5: 5: 5: 2$.

\section{Kesimpulan}

Kandungan kalsium biji kelor menggunakan flame photometer dengan tiga kali pengulangan adalah $120 \pm 13,91, \quad 145 \pm 15,89, \quad 130 \pm 2,00$ $\mathrm{mg} / 100 \mathrm{~g}$ dan komposisi bahan yang tepat untuk membuat pasta gigi dari biji kelor meliputi uji kekesatan dari pasta gigi berdasarkan kesukaan panelis yaitu dengan perbandingan biji kelor dan $\mathrm{NaHCO} 3$ sebanyak 25 : 3. Sedangkan untuk uji kesegaran, aroma dan warna dengan perbandingan gliserin, daun mint, daun sirih dan pewarna makanan sebanyak $7,5: 5: 5: 2$.

\section{Ucapan Terima Kasih}

Penulis mengucapkan terima kasih kepada kepala laboran laboratorium Kimia FKIP UNTAD dan semua pihak yang telah membantu dalam pelaksanaan penelitian ini.

\section{Referensi}

Afrianti\& Harun. (2011). Penentuan kadar kalsium pada ikan kering air laut dan ikan kering air tawar dengan metoda spektrofotometri serapan atom. Jurnal Farmasi dan Kesehatan, 1(2), 18-24.

Almaitser. (2004). Prinsip dasar ilmu gizi. Jakarta: PT Gramedia Pustaka Utama.

Becker, K.,\& Makkar, H.P.S. (1996). Nutritional value and antinutritional component of whole and ethanol extracted moringa oleifera leaves. Journal of Feed Science and Tecnology, 63, 211-228.

Boukes, G.J., Venter, M.V.D., \& Oosthuizen, V. (2008). Quantitative and qualitative analysis of sterols/sterolins and hypoxoside contents of three hypoxis (African potato) spp. African Journal of Biotechnology, 7(11), 1624-1629.

Cahyadi. (2006). Analisis dan aspek kesehatan bahan tambahan pangan. Jakarta: Bumi Aksara.

Day, R.A.,\& Underwood, A.L. (2003). Analisis kimia kuantitatif. Edisi keenam. Jakarta: Erlangga.

Fahey, J.W. (2005). Moringa oleifera: a review of the medical evidence for its nutritional, therapeutik, and prophylactic properties. Part 1.

Hariana. (2008). Tumbuhan obat dan khasiatnya. Jakarta: Niaga Swadaya.

Hendayana, S. (1994). Kimia analitik instrumen. Edisi kesatu. Semarang: IKIP Semarang Press.

Kholis, N., \& Hadi, F. (2010). Pengujian bioassay biskuit balita yang disuplementasi konsentrat protein daun kelor (moringa oleifera) pada model tikus malnutrisi. Jurnal Tekhnologi Pertanian, 11(3), 144-151.

Khopkar, S.M. (2010). Konsep dasar kimia analitik. Jakarta: UI-Press.

Maharani., Endang., \& Harsoel, I. (2009). Analisis kadar detergent anionik pada sediaan pasta gigi anak-anak. Jurnal Kesehatan, 2(2).

Marzuki, A., Fujaya, Y., Muhammad, R., \& Haslina. (2013). Analisis kandungan 
kalsium ( $\mathrm{Ca}$ ) dan besi ( $\mathrm{Fe}$ ) pada kepiting bakau (scylla olivacea) cangkang keras dan cangkang lunak dengan spektrofotometri serapan atom. Majalah Farmasi dan Farmakologi, 12(2).

Putri. (2008). Pengujian mutu pasta gigi sesuai SNI (12 - 3524 - 1995). Bogor: Akademi Kimia Analisis.

Sutanto, T., Adfa, D., \& Taringan, N. (2007).

Buah kelor (moringa oleifera lamk.) tanaman ajaib yang dapat digunakan untuk mengurangi kadar ion logam dalam air. Jurnal Gradien, 3(1), 219-221.

Wihastuti., Titin, A., Sargowo, D., \& Rohman, M.S. (2007). The effect of moringa oleifera leaf extractin inhibition of NFKB activation,TNF- $\alpha$ and ICAM1 expressionin oxydized LDL treated HUVECS. Jurnal Kardiologi Indonesia, 28, 181-188.

Winarno, F.G. (2004). Kimia pangan dan gizi. Jakarta: PT. Gramedia. 